Journal of Computer Networks, Architecture and

High Performance Computing

Volume 3 Number 2, July 2021

https://doi.org/10.47709/cnahpc.v3i2.990

Submitted : 21 June 2021

Accepted : 27 June 2021

Published : 5 July 2021

\title{
Impact of Online Learning in the Era Pandemic Using the Algorithm C 4.5
}

\author{
Windania Purba ${ }^{1)^{*}}$, Desty Rukmana Kumala Sari ${ }^{2)}$, Derry Rosanta Br.sitanggang ${ }^{3)}$, Lina Sari \\ Harefa ${ }^{4)}$ \\ 1)23)44)Universitas Prima Indonesia, Indonesia \\ ${ }^{1)}$ winda.nia04@gmail.com, ${ }^{2}$ destyrukmana123@gmail.com, ${ }^{3)}$ deryrosantasitanggang@gmail.com, \\ 4)
}

\begin{abstract}
The presence of the Corona virus disease 2019 (Covid-19) pandemic has changed the order in all corners of the world in a very short time. This large-scale change has occurred in the last two years starting from 2019 until now. This has resulted in the world of education experiencing major changes in the teaching and learning process. The learning process during the COVID-19 pandemic (online) is very much different from the previous learning process (face to face). This is a big problem in the world of education. The online learning policy, which was thought to be the solution to this problem, turned out to be just a bridge to break the passion for learning for students. evidenced by the impact felt by students during online learning. The satisfaction of online learning by Prima Indonesia University students can be seen from the results of the keosener (google form) that the researcher has distributed to 501 students. Researchers use data mining to explore important information that is expected to be used as consideration for enforcing the current online learning process. Researchers use the C 4.5 Algorithm method in data mining in order to bring out the impact of online learning. Measurement of satisfaction level is done by calculating the Entropy and Gain of each data that becomes a Decision tree and testing the results using Rapid Miner. The C 4.5 algorithm is very helpful for researchers to find out the impact of online learning carried out during the covid 19 pandemic. From the results of calculations and testing, it shows that there is a decrease in student interest in learning in the online learning process. this concludes that online learning in the pandemic era has a negative impact on students at Prima Indonesia University.
\end{abstract}

Keywords: C 4.5 Algorithm, Data Mining, Impact Online, Rapid Miner.

\section{INTRODUCTION}

As lightning is very fast, so are technological developments today. It is inevitable, that technology is very influential in all human activities. Not only is the development so fast, technology is also very much needed at times like this, especially during the COVID-19 pandemic situation that has occurred in the last two years. The increasing use of technology is felt in the world of education. This happens because of the policies taken by the government to carry out the online learning process. That means, technology plays an important role in the world of education during the current pandemic. Educational Technology is a sequential step in designing, implementing and evaluating the overall process of learning and learning in the form of unique learning outcomes, studies and ethics of application to support and enhance the passion of learning performance. The study and ethics of such practice can be through the creation, use, regulation of processes, and technological resources. Educational technology is a combination of human elements, machines, ideas, steps, and management.(Raja \& Nagasubramani, 2018): At the end of 2019, the world was shocked by the corona virus disease 19 or covid 19. Covid 19 is a contagious disease outbreak caused by the acute respiratory syndrome Coronavirus 2 (Server acute respiratory syndrome Coronavirus 2 or SARSCoV-2). This virus belongs to the Coronavirus family that can infect animals. When this virus attacks humans, Coronavirus usually causes respiratory tract infections, such as the flu, MERS (Middle East Respiratory Syndrome). COVID-19 itself is a new type of coronavirus that was discovered in Wuhan, Hubei, China in 2019. (To et al., 2021): As a result of this virus, the government has taken steps for the world of education. Namely by enforcing policies on teaching and learning processes online or online. All students are encouraged to be willing to carry out the online learning process. Because of this policy, researchers are moving to examine the impact of online learning. no one suspected that it turned out that this step that was considered appropriate was not in accordance

* Corresponding author

This is an Creative Commons License This work is licensed under a Creative

Commons Attribution-NoDerivatives 4.0 International License. 


\section{Journal of Computer Networks, Architecture and High Performance Computing}

Volume 3 Number 2, July 2021

https://doi.org/10.47709/cnahpc.v3i2.990
Submitted : 21 June 2021

Accepted : 27 June 2021

Published : 5 July 2021

with what was expected by the government. in fact, many students complain about the current policies, this is clearly shown in the results of the research examined by researchers, researchers reveal that students' dissatisfaction with the online learning process. With this research, the online teaching and learning process is considered by the government, seeing a decrease in learning interest due to the online learning process..

\section{LITERATURE REVIEW}

Data Mining is a series of ways and processes to get more value from a combination of data in the form of knowledge that has not been known in general so far. (Riyanto, Hamid, \& Ridwansyah, 2019):.Data mining can also be referred to as a way to describe and search for discoveries in the form of knowledge contained in databases. Data mining has broad roots in the field of science in the form of artificial intelligence (artificial intelligent), machine learning, statistics and databases. The $\mathrm{C} 4.5$ algorithm is a calculation that will produce a decision tree that can be used to predict a decision by performing a decision rule step. The use of decision trees is very useful for determining the decisions to be taken. In addition, the $\mathrm{C} 4.5$ algorithm is widely used to predict everything that has a decision. The $\mathrm{C} 4.5$ algorithm is also one of the processes of making a decision tree according to the existing training data. Decision tree is a very powerful and well known and accurate method of classification and prediction. The decision tree method converts very large facts into a decision tree that outlines the rules.(Darmawan, 2018):. For more than two years we have been trying to avoid the corona virus disease or covid-19. Many regulations have been enforced in Indonesia due to the COVID-19 pandemic. Starting from the rules for Large-Scale Social Restrictions in the Context of Accelerating the Handling of Covid-19, the rules for working from home (work from home), as well as online learning (E-Learning) for students in accordance with applicable regulations. regulations.(Huynh \& Bachelor, 2020):. Government program regulations to break the chain of the very deadly COVID-19 (coronavirus) pandemic. However, complaints from students who compare the online learning process with face-to-face are often heard. students feel that the online learning process carried out in the pandemic era in the last two years has had a bad impact. Students admit that the online learning process reduces their interest in learning, so the value they get will decrease. Not enough, students are also not satisfied with the current online learning process, this is very different from the previous learning process (face to face). Learning media must be something that can convey or distribute messages from a learning source in a planned manner, so that there is a supportive learning environment where recipients can carry out the learning process efficiently and effectively. But in reality online-based learning media that is happening today brings new impacts for students. For this reason, this is the basic material for researchers to conduct research in the hope that it can be taken into consideration and help for further research.

\section{METHOD}

Research that is used as a plan and investigation is arranged in such a way, making it easier for researchers to get answers to research questions. The plan is a comprehensive scheme that includes the research program(Asenahabi, 2019):. The process that is carried out first is to describe the problems that are happening in the surrounding environment. Analysis is done to find out how the picture of a problem to get a solution to the problems that occur. Literature study is a series of activities in the process of collecting data needed in the research process, then calculating entropy and gain from the data that has been collected (data set). And testing is done at the end after obtaining the results of the calculations. This research design was made as a research approach model which is also a data analysis design. The following is a picture of the research design/research design described by the researcher: 


\section{Journal of Computer Networks, Architecture and High Performance Computing}

Submitted : 21 June 2021

Volume 3 Number 2, July 2021

https://doi.org/10.47709/cnahpc.v3i2.990

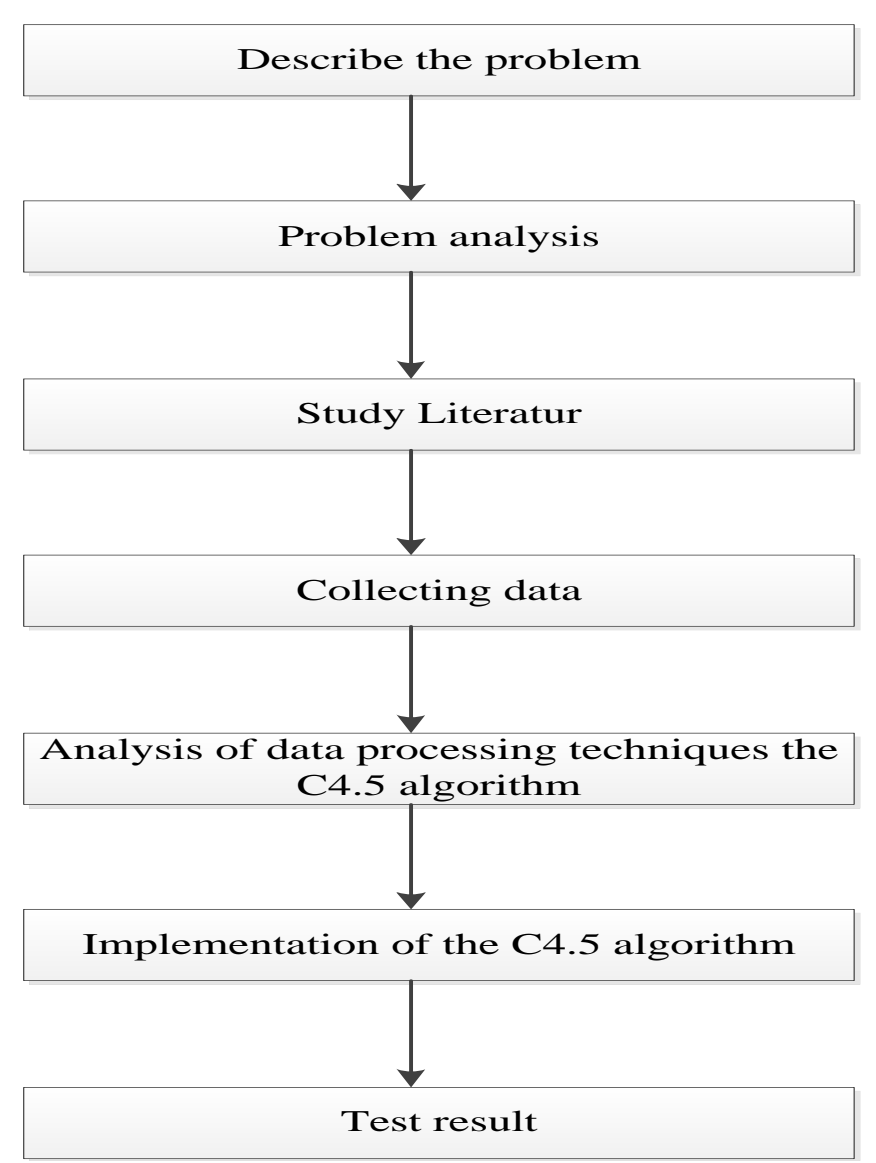

Fig.1 Research design

\section{Respondent Data}

RESULT

Researchers conducted research on 501 students from various levels and study programs at the University of Prima Indonesia. There are 14 questions asked by researchers in the questions distributed to Prima Indonesia University students via Google Form. all questions in the questionnaire were questions related to online learning experienced by students during the covid 19 pandemic. Some of the questions researchers asked students, such as, what are the obstacles to online learning that students feel, how satisfied are students when doing online learning in the pandemic era, what applications do students use during the online learning process, as well as student impressions and messages during the online learning process. during the pandemic and many other questions. all questions in the questionnaire are questions related to online learning experienced by students during the covid 19 pandemic. From the questions asked to students at the prima indonesia university, the researchers hope that the results or answers to these questions get facts related to the impact of online learning during this covid 19 pandemic. The following are the results of the questionnaire distributed by researchers to Prima Indonesia University students: 


\section{Journal of Computer Networks, Architecture and High Performance Computing}

Volume 3 Number 2, July 2021

https://doi.org/10.47709/cnahpc.v3i2.990
Submitted : 21 June 2021

Accepted : 27 June 2021

Published : 5 July 2021

\begin{tabular}{|c|c|c|c|c|c|c|c|c|c|c|c|c|}
\hline 1 & Timestamp & Name & & Faculty & Student Status & GPA & B GPA & Does & (What obstacles di & iHas : & y What impact have you had on online learn & i The media you use whe \\
\hline 2 & $11 / 30 / 202011: 44: 03$ & Nita Kurnia & 7 & Faculty of Tecnology and cot & Only Lecture & 3,67 & 3,57 & No & run out of quota & Yes & I'm lazy to study & Spada \\
\hline 3 & $11 / 30 / 202012: 04: 26$ & Dery Rosanta Br Sitanggang & 7 & Faculty of Tecnology and cot & 1 Only Lecture & 3,48 & 3,48 & No & Internet Network & Yes & Intention to learn decreases & Zoom, WA, Spada \\
\hline 4 & $11 / 30 / 202012: 14: 49$ & Lina Sari Harefa & 7 & Faculty of Tecnology and cot & tecture \& Work & 3,78 & 3,25 & No & run out of quota & Yes & Ineffective study & Spada \\
\hline 5 & $1 / 6 / 202123: 09: 42$ & Desty Rukmana & 7 & Faculty of Tecnology and cor & Only Lecture & 3,76 & 3,67 & No & Internet Network & Yes & I'm not excited to learn & Spada \\
\hline 6 & $1 / 6 / 202123: 45: 15$ & Lina Sari & 7 & Faculty of Tecnology and cot & Lecture \& Work & 3,84 & 3,42 & No & run out of quota & Yes & Decreased interest in learning & Spada \\
\hline 7 & $2 / 5 / 202120: 25: 15$ & Rayman & 3 & Economy & Only Lecture & 3,34 & 3,28 & No & Internet Network & Yes & Lack of understanding about learning & Zoom, WA, Spada \\
\hline 8 & $2 / 5 / 202120: 34: 53$ & Lilis Sumatris Marpaung & 4 & Faculty of Law & Only Lecture & 3,75 & 3,51 & No & Internet Network & Yes & Value decreased and ran out of quota & Zoom, WA, Spada \\
\hline 9 & $2 / 5 / 202120: 41: 38$ & Mira Zahukhu & 3 & Economy & Only Lecture & 3,3 & 3,33 & No & run out of quota & Yes & Don't understand the lesson & Spada \\
\hline 10 & 2/5/2021 21:08:36 & Ningsih Mawarni & 8 & Faculty of Tecnology and cot & Only Lecture & 3,73 & 3,35 & No & run out of quota & Yes & Value decreased and ran out of quota & Spada \\
\hline 11 & 2/5/2021 21:09:31 & Lisa zendrato & 3 & Kesmas & Only Lecture & 3,88 & 3,36 & Yes & Internet Network & Yes & All values are down & Zoom, WA, Google MeI \\
\hline 12 & 2/5/2021 21:35:12 & Ririn Hutauruk & 4 & Economy & Only Lecture & 3,76 & 3,3 & No & Internet Network & Yes & Ineffective study & Zoom, Google Meeting, \\
\hline 13 & $2 / 6 / 20219: 01: 41$ & Jodi alexsander laia & 7 & Faculty of Tecnology and cor & Lecture \& Work & 3 & 3 & No & Internet Network & No & Can't understand the lesson & Zoom, WA, Spada \\
\hline 14 & $2 / 6 / 2021 \quad 10: 21: 35$ & Dedi Hutabarat & 5 & \begin{tabular}{|l|} 
Public Healt \\
\end{tabular} & Jonly Lecture & 3,7 & 3,42 & No & no problem & No & I'm lazy to study & Zoom, WA, Spada \\
\hline 15 & $2 / 7 / 2021 \quad 13: 59: 44$ & David & 6 & Ekonomi & Only Lecture & 3,2 & 3,1 & No & no problem & Yes & So stupid & Zoom, WA, Spada \\
\hline 16 & $2 / 15 / 20219: 11: 31$ & Retzky Witra & 7 & Faculty of Tecnology and cot & Only Lecture & 3,78 & 3,9 & Yes & Internet Network & Yes & Cannot meet face to face with lecturers a & Zoom, WA, Spada \\
\hline 17 & $2 / 15 / 20219: 45: 11$ & Jurmida Pulungan & 7 & Faculty of Tecnology and cot & Only Lecture & 3,43 & 3,76 & No & Internet Network & Yes & For theoretical learning it can still be follor & Woom, Google Meeting, \\
\hline 18 & $2 / 15 / 202114: 15: 25$ & krisman simatupang & 7 & Faculty of Tecnology and cot & Only Lecture & 4 & 3,5 & No & Internet Network & Yes & so lazy to study & Spada \\
\hline 19 & $3 / 22 / 202120: 42: 43$ & Salmiati & 8 & Faculty of Tecnology and cot & Only Lecture & 3,65 & 3,42 & No & run out of quota & Yes & Being lazy to study & Spada \\
\hline 20 & $3 / 22 / 202120: 53: 58$ & Juan Alexander Silitonga & 8 & Faculty of Tecnology and cor & t Lecture \& Work & 3,59 & 3,31 & No & run out of quota & Yes & Passion for learning according to & Spada \\
\hline 21 & 3/22/2021 21:07:21 & Krisman Simatupang & 8 & Faculty of Tecnology and cor & Lecture \& Work & 3,78 & 3,46 & No & run out of quota & Yes & Students do not understand the material gi & ii Spada \\
\hline 22 & 3/22/2021 21:16:10 & Ristya febriani br ks & 8 & Faculty of Tecnology and cot & Only Lecture & 3,7 & 3,3 & No & no problem & Yes & Become lazy & Spada \\
\hline 23 & $3 / 22 / 202121: 54: 59$ & tesalonika & 3 & Economy & Only Lecture & 3,84 & 3,8 & No & run out of quota & Yes & Passion for learning according to & Spada \\
\hline 24 & $3 / 22 / 202121: 54: 59$ & sari & 3 & Economy & Only Lecture & 3,78 & 3,68 & No & run out of quota & Yes & I'm lazy to study & Spada \\
\hline 25 & $3 / 22 / 202121: 58: 58$ & Bonita Lestari Sianipar & 8 & Faculty of Tecnology and cor & t Lecture \& Work & 3,98 & 3,45 & No & Internet Network & Yes & Less specific and unclear learning & Zoom, WA, Spada \\
\hline$a r$ & 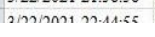 & 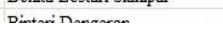 & 2 & 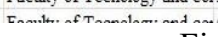 & Hall. T mather & 2 & $21 n$ & Nin & 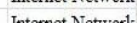 & & 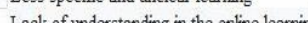 & 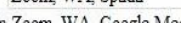 \\
\hline
\end{tabular}

Fig. 2 Respondent Data

\section{Data Traning}

Training data is taken from previous data, namely respondent data that has been grouped into certain classes or attributes. The following is an image showing the data traning.

Table 1

Data Traning

\begin{tabular}{|c|c|c|c|c|c|}
\hline Name & Student Status & $\begin{array}{l}\text { Maximum } \\
\text { Learning }\end{array}$ & Online Obstacle & Interest to learn & Impact \\
\hline Nita Kurnia & Only Lecture & Not & Internet Network & down & Negatif \\
\hline DeryRosantaBr Sitanggang & Only Lecture & Not & Internet Network & down & Negatif \\
\hline Lina Sari Harefa & Lecture \& Work & Not & out of quota & down & Negatif \\
\hline Desty Rukmana & Only Lecture & Not & Internet Network & down & Negatif \\
\hline Lina Sari & Lecture \& Work & Not & out of quota & down & Negatif \\
\hline Rayman & Only Lecture & Not & Internet Network & down & Negatif \\
\hline Lilis Sumatris Marpaung & Only Lecture & Not & Internet Network & down & Negatif \\
\hline Mira Zalukhu & Only Lecture & Not & out of quota & down & Negatif \\
\hline Ningsih Mawarni & Only Lecture & Not & out of quota & down & Negatif \\
\hline Lisa zendrato & Only Lecture & Yes & Internet Network & down & Negatif \\
\hline Ririn Hutauruk & Only Lecture & Not & Internet Network & down & Negatif \\
\hline Jodi alexsander laia & Lecture \& Work & Not & Internet Network & Not Decrease & Positif \\
\hline Dedi Hutabarat & Only Lecture & Not & no problem & Not Decrease & Positif \\
\hline David & Only Lecture & Not & no problem & down & Negatif \\
\hline Retzky Witra & Only Lecture & Yes & Internet Network & down & Negatif \\
\hline Jurmida Pulungan & Only Lecture & Not & Internet Network & down & Negatif \\
\hline krisman simatupang & Only Lecture & Not & Internet Network & down & Negatif \\
\hline Salmiati & Only Lecture & Not & out of quota & down & Negatif \\
\hline Juan Alexander Silitonga & Lecture \& Work & Not & out of quota & down & Negatif \\
\hline Krisman Simatupang & Lecture \& Work & Not & out of quota & down & Negatif \\
\hline Ristya febriani br ks & Only Lecture & Not & no problem & down & Negatif \\
\hline Evalinda & Only Lecture & Not & out of quota & down & Negatif \\
\hline Evylinda & Only Lecture & Not & out of quota & down & Negatif \\
\hline
\end{tabular}




\section{Journal of Computer Networks, Architecture and High Performance Computing}

Submitted : 21 June 2021

Volume 3 Number 2, July 2021

https://doi.org/10.47709/cnahpc.v3i2.990

\section{Calculation of Algorithm C 4.5}

Calculation of $\mathrm{C}$ algorithm 4.5 is carried out to find roots, branches to become a decision tree. In this process, the calculation is done more than once, and it is calculated using Microsoft Office Excel using a formula. Entropy calculation using the formula $=(-$ Positive/autotal)*IMLOG2 $\quad$ (Positive/autotal+(-negative/autotal*IMLOG2 (Negative/autotal)) in excel, and gain calculation using the Gain=(Total Entropy) formula ((Amount max/auto)*Entropymax $)(($ Number max/auto)*Entropy not max $)$ in an Excel cell.

Table 2

Entropy and Gain Calculation

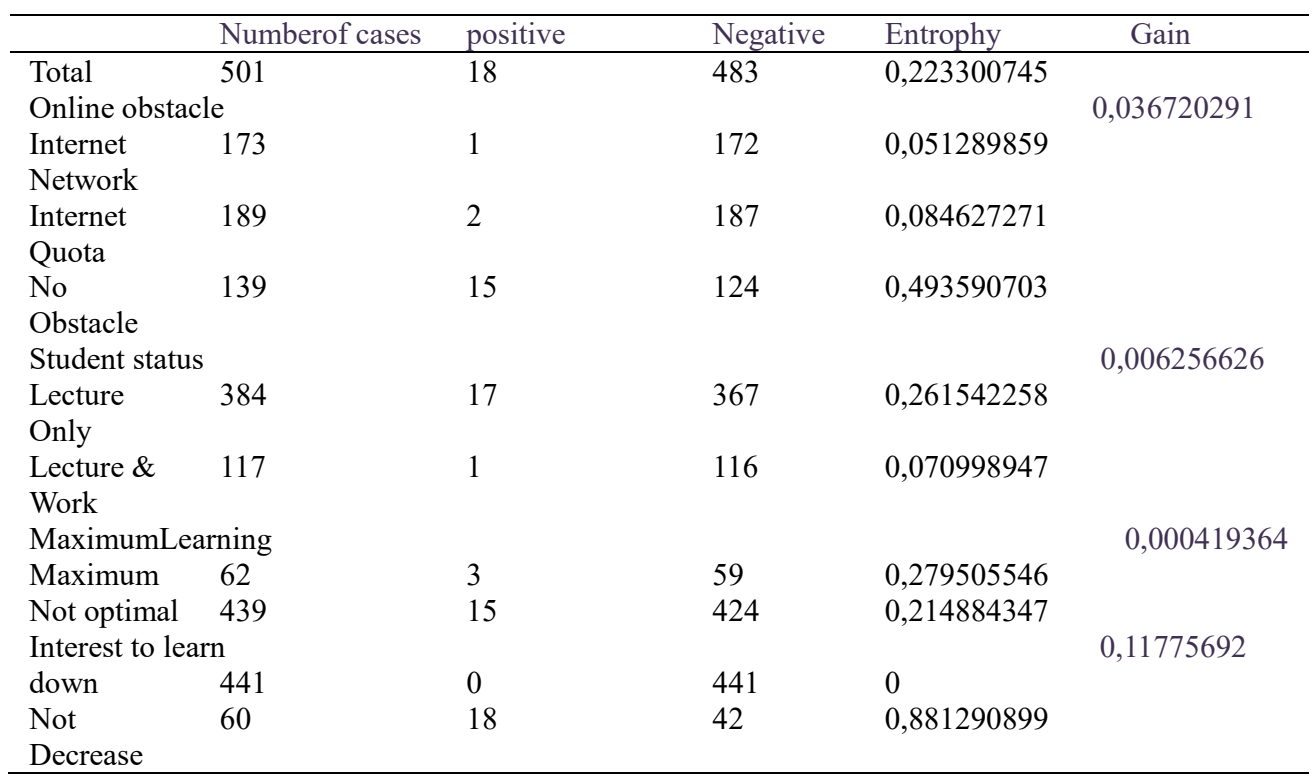

Table 3

Entropy and Gain Calculation

\begin{tabular}{|c|c|c|c|c|c|}
\hline & $\begin{array}{l}\text { Numberof } \\
\text { Cases }\end{array}$ & Positive & Negative & Entrophy & Gain \\
\hline Total & 287 & 17 & 270 & 0,324394455 & \multirow{6}{*}{0,265122723} \\
\hline \multirow{2}{*}{\multicolumn{5}{|c|}{$\begin{array}{l}\text { Interest in Learning Doesn't Decrease } \\
\text { Online Obstacle }\end{array}$}} & \\
\hline & & & & & \\
\hline $\begin{array}{l}\text { Internet } \\
\text { Network }\end{array}$ & 198 & 0 & 198 & 0 & \\
\hline Internet & 67 & 0 & 67 & 0 & \\
\hline No & 22 & 17 & 5 & 0,773226674 & \\
\hline \multicolumn{5}{|c|}{ MaximumLearning } & \multirow{3}{*}{0,10324764} \\
\hline Maximum & 17 & 10 & 7 & 0,977417818 & \\
\hline Not optimal & 270 & 7 & 63 & 0,17352975 & \\
\hline
\end{tabular}




\section{Journal of Computer Networks, Architecture and High Performance Computing}

Submitted : 21 June 2021

Volume 3 Number 2, July 2021

https://doi.org/10.47709/cnahpc.v3i2.990

Table 4

Entropy and Gain Calculation

\begin{tabular}{|c|c|c|c|c|c|}
\hline & $\begin{array}{l}\text { Numberof } \\
\text { Cases }\end{array}$ & Positive & Negative & Entrophy & Gain \\
\hline Total & 96 & 12 & 84 & 0,543564443 & \\
\hline \multicolumn{5}{|c|}{$\begin{array}{l}\text { Interest in Learning Doesn't Decrease } \\
\text { Online Barriers No Obstacles }\end{array}$} & 0,265122723 \\
\hline \multicolumn{5}{|c|}{ Maximum Learning } & 0.45727883 \\
\hline Maximum & 14 & 12 & 2 & 0,591672779 & \\
\hline Not optimal & 82 & 0 & 82 & 0 & \\
\hline \multicolumn{5}{|c|}{ Student Status } & 0,543564443 \\
\hline $\begin{array}{l}\text { Lecture } \\
\text { Only }\end{array}$ & 74 & 0 & 84 & 0 & \\
\hline $\begin{array}{l}\text { Lecture \& } \\
\text { Work }\end{array}$ & 22 & 12 & 0 & 0 & \\
\hline
\end{tabular}

After processing the data and calculating the Entropy and Gain, then determining the highest Gain and finding the attributes of the gain. The selected gain and attribute will be the initial root, then the process of determining the branch of the gain, and making a decision tree using the results of calculations and gains that have been done. The following are the results of the calculation of etrophy and gain to produce a decision tree:

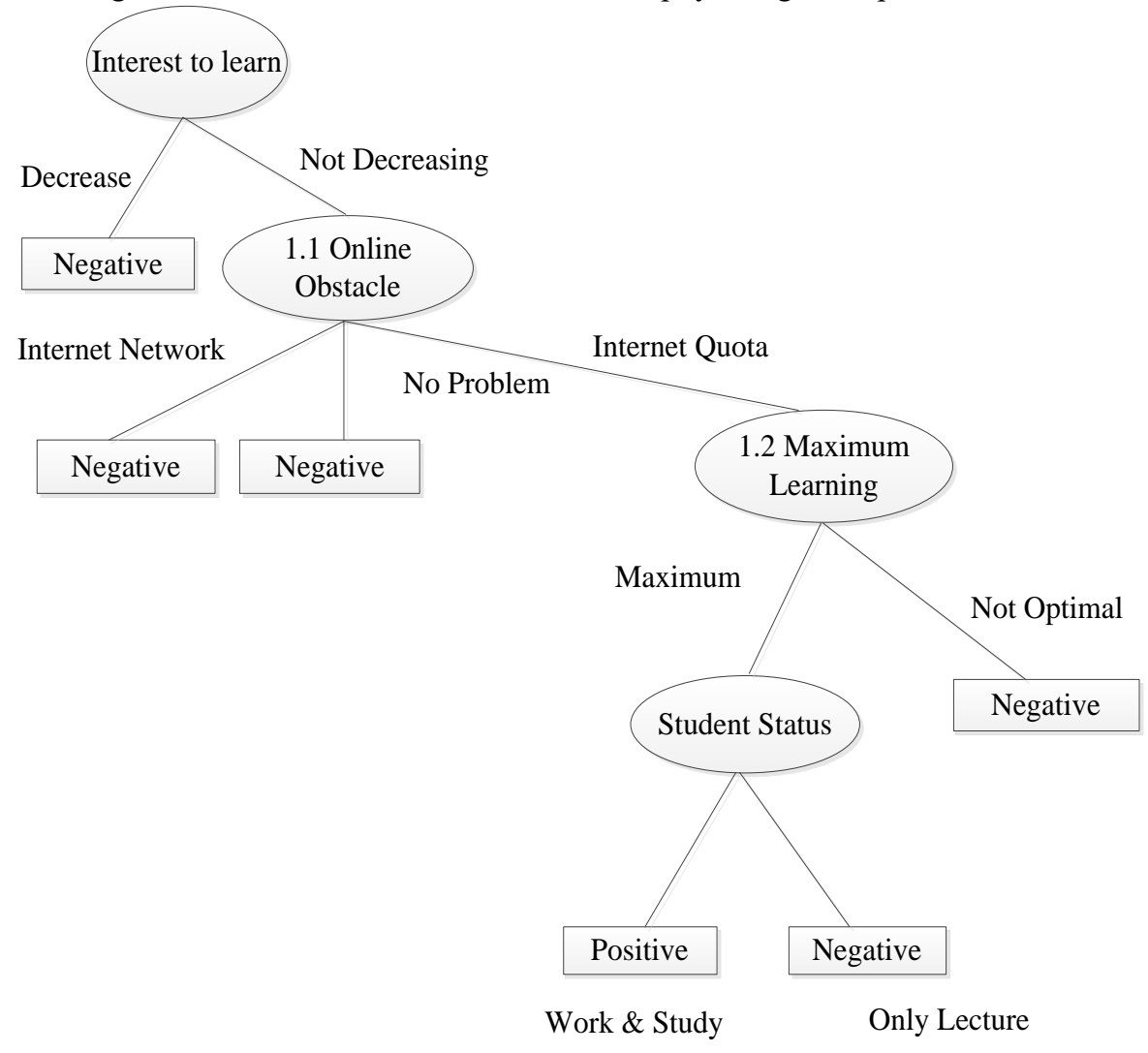

Fig. 3 Decision Tree 


\section{Journal of Computer Networks, Architecture and High Performance Computing}

Submitted : 21 June 2021

Volume 3 Number 2, July 2021

https://doi.org/10.47709/cnahpc.v3i2.990

Accepted : 27 June 2021

Published : 5 July 2021

\section{TESTING USING RAPID MINER}

\section{DISCUSSIONS}

After calculating the data in Microsoft Office Excel and producing a decision tree, the researcher then conducts the testing process. This testing process is carried out with the Rapid Miner application. And the results concluded that both of them showed the same result, namely the fact that the online learning done by students at the Prima Indonesia University had a negative impact. This is indicated by the decrease in students' interest in learning to carry out the online learning process.

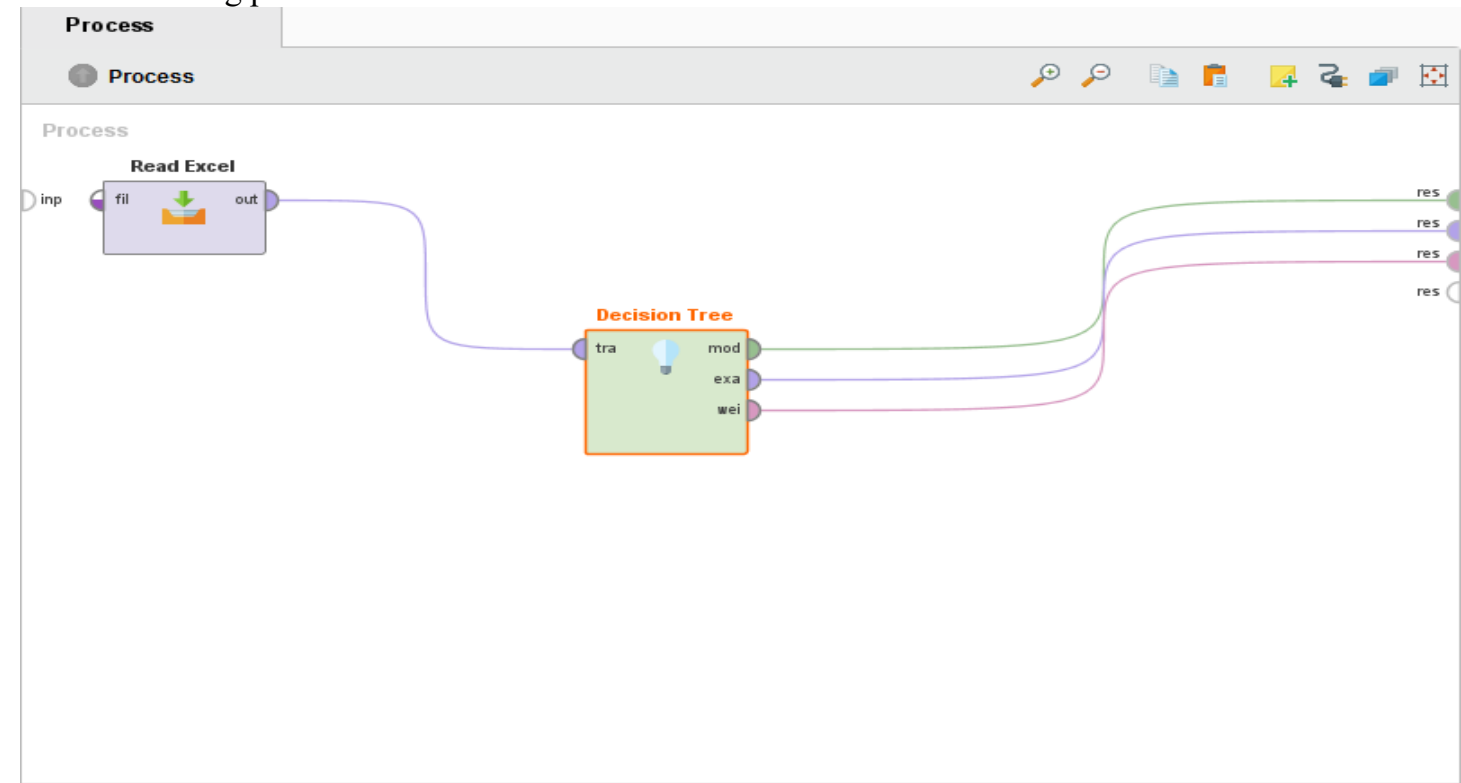

Fig. 4 Rapid Miner Testing Process

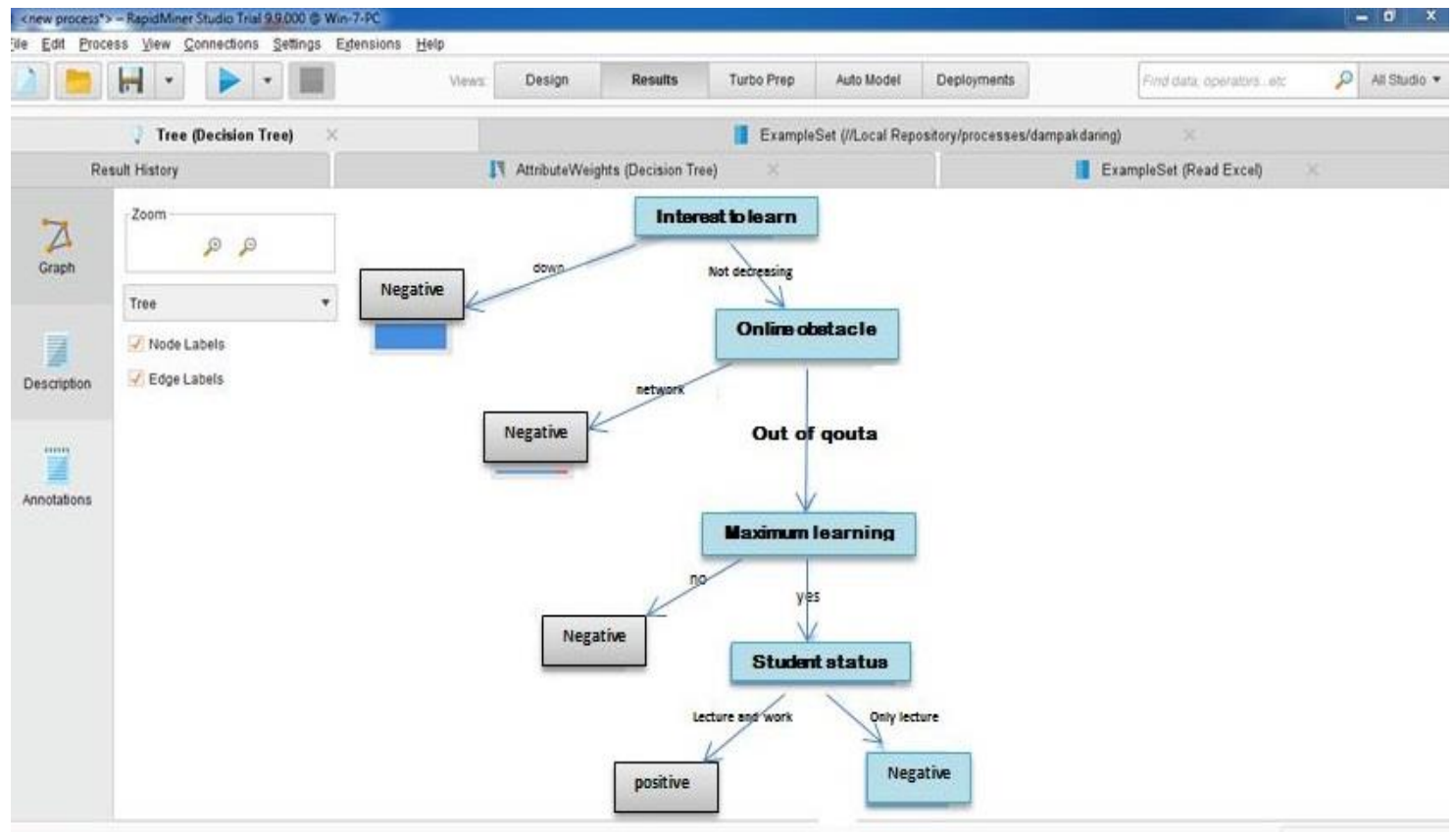

Fig. 5 Decision Tree 


\section{Journal of Computer Networks, Architecture and High Performance Computing}

Volume 3 Number 2, July 2021

https://doi.org/10.47709/cnahpc.v3i2.990
Submitted : 21 June 2021

Accepted : 27 June 2021

Published : 5 July 2021

The goals and results of each researcher's research are certainly different. Various results are displayed by researchers. in previous studies, the results of the brave learning process may have positive or negative impacts according to the results of the study, however, in this study, which was late, the researchers revealed the fact that the brave learning process in the pandemic era with case studies at Prima Indonesia University got negative results. This is due to the decreased interest in learning for Prima Indonesia University students during the Covid-19 pandemic.

\section{CONCLUSION}

After a survey of 501 Indonesian university students who carried out the online learning process found a new fact, namely a decrease in interest in learning during the covid 19 pandemic. This is shown from table 1 to table 3 (table for calculating entropy and gain) which shows that the results of the calculation and tree negative decisions. from the results that can be seen in Figure vi (the process of testing the results), showing the match between the calculation results and the test results using rapid miner software.For this reason, the researchers concluded that online learning during the pandemic had a negative impact on students at Prima Indonesia University. In addition to having a negative impact on students, online learning also affects the level of student learning satisfaction during a pandemic.

\section{REFERENCES}

Al-Najar, H., \& Hamarneh, B. E. L. (2019). The effect of education level on accepting the reuse of treated effluent in irrigation. Indonesian Journal of Science and Technology, 4(1), 28-38. doi:10.17509/ijost.v4i1.14881

(Asenahabi, 2019):

Asenahabi, B. M. (2019). Qualitative research, Mixed method research. International Journal of Contemporary Applied Researches, 6(5), 76-87. Retrieved from www.ijcar.net

(Darmawan, 2018)

Darmawan, E. (2018). C4.5 Algorithm Application for Prediction of Self Candidate New Students in Higher Education. Jurnal Online Informatika, 3(1), 22. doi:10.15575/join.v3i1.171

Hashim, S., Masek, A., Abdullah, N. S., Paimin, A. N., \& Muda, W. H. N. W. (2020). Students' intention to share information via social media: A case study of COVID-19 pandemic. Indonesian Journal of Science and Technology, 5(2), 236-245. doi:10.17509/ijost.v5i2.24586

Istiawan, D., \& Khikmah, L. (2019). Implementation of C4.5 Algorithm for Critical Land Prediction in Agricultural Cultivation Areas in Pemali Jratun Watershed. Indonesian Journal of Artificial Intelligence and Data Mining, 2(2), 67. doi:10.24014/ijaidm.v2i2.7569

Lone, S. A., \& Ahmad, A. (2020). COVID-19 pandemic-an African perspective. Emerging Microbes and Infections, 9(1), 1300-1308. doi:10.1080/22221751.2020.1775132

Mulyanti, B., Purnama, W., \& Pawinanto, R. E. (2020). Distance learning in vocational high schools during the covid-19 pandemic in West Java province, Indonesia. Indonesian Journal of Science and Technology, 5(2), 271-282. doi:10.17509/ijost.v5i2.24640

Putra, Z. A., \& Abidin, S. A. Z. (2020). Application of seir model in covid-19 and the effect of lockdown on reducing the number of active cases. Indonesian Journal of Science and Technology. doi:10.17509/ijost.v5i2.24432

Rahayu, G. D. S., \& Fauzi, M. R. (2020). The Effect of the Project-Based Learning Model on Students' Resilience During the Pandemic Covid-19. JPI (Jurnal Pendidikan Indonesia), 9(4), 711. doi:10.23887/jpiundiksha.v9i4.27390

Rahmat, A., Hamid, M. A., Zaki, M. K., \& Mutolib, A. (2018). Normalized difference vegetation index (NDVI) in the integration conservation education forest at Wan Abdul Rachman using modis data. Indonesian Journal of Science and Technology, 3(1), 47-52. doi:10.17509/ijost.v3i1.10798

(Raja \& Nagasubramani, 2018):

Raja, R., \& Nagasubramani, P. C. (2018). Impact of modern technology in education. Journal of Applied and Advanced Research, 3(S1), 33. doi:10.21839/jaar.2018.v3is1.165

(Riyanto, Hamid, \& Ridwansyah, 2019):

Riyanto, V., Hamid, A., \& Ridwansyah, R. (2019). Prediction of Student Graduation Time Using the Best Algorithm. 


\section{Journal of Computer Networks, Architecture and High Performance Computing}

Submitted : 21 June 2021

Volume 3 Number 2, July 2021

https://doi.org/10.47709/cnahpc.v3i2.990

Indonesian Journal of Artificial Intelligence and Data Mining, 2(1), 1-9. doi:10.24014/ijaidm.v2i1.6424

Sangsawang, T. (2020). An instructional design for online learning in vocational education according to a selfregulated learning framework for problem solving during the covid-19 crisis. Indonesian Journal of Science and Technology, 5(2), 283-198. doi:10.17509/ijost.v5i2.24702

(To et al., 2021):

To, K. K. W., Sridhar, S., Chiu, K. H. Y., Hung, D. L. L., Li, X., Hung, I. F. N., ... Yuen, K. Y. (2021). Lessons learned 1 year after SARS-CoV-2 emergence leading to COVID-19 pandemic. Emerging Microbes and Infections, 10(1), 507-535. doi:10.1080/22221751.2021.1898291

Wu, X., Kumar, V., Ross, Q. J., Ghosh, J., Yang, Q., Motoda, H., ... Steinberg, D. (2008). Top 10 algorithms in data mining. Knowledge and Information Systems (Vol. 14). doi:10.1007/s10115-007-0114-2 